The effect of firms' partial retirement policies on the labour market outcomes of their employees

Martin Huber, Michael Lechner, Conny Wunsch

July 2013 Discussion Paper no. 2013-16 


$\begin{array}{ll}\text { Editor: } & \text { Martina Flockerzi } \\ & \text { University of St.Gallen } \\ & \text { School of Economics and Political Science } \\ & \text { Department of Economics } \\ & \text { Bodanstrasse 8 } \\ & \text { CH-9000 St. Gallen } \\ & \text { Phone } \quad+41712242325 \\ & \text { Fax } \quad+41712243135 \\ & \text { Email seps@unisg.ch } \\ & \text { School of Economics and Political Science } \\ & \text { Department of Economics } \\ & \text { University of St.Gallen } \\ & \text { Bodanstrasse } 8 \\ \text { Publisher: } & \text { CH-9000 St. Gallen } \\ & \text { Phone +41 71 224 23 25 } \\ & \text { Fax }+41712243135 \\ & \text { http://www.seps.unisg.ch }\end{array}$




\title{
The effect of firms' partial retirement policies on the labour market outcomes of their employees
}

\author{
Martin Huber, Michael Lechner, Conny Wunsch ${ }^{1}$
}

$\begin{array}{ll}\text { Author's address: } & \text { Prof. Martin Huber } \\ \text { Swiss Institute for Empirical Economic Research } \\ \text { Varnbüelstrasse } 14 \\ 9000 \text { St. Gallen } \\ \text { Phone } \quad+41712242814 \\ \text { Fax } \quad+41712242302 \\ \text { Email michael.lechner@unisg.ch } \\ \text { Website www.sew.unisg.ch } \\ \text { Prof. Dr. Michael Lechner } \\ \text { Swiss Institute for Empirical Economic Research } \\ \text { Varnbüelstrasse 14 } \\ \text { 9000 St. Gallen } \\ \text { Phone +41 71 224 28 14 } \\ \text { Fax } \quad+41712242302 \\ \text { Email michael.lechner@unisg.ch } \\ \text { Website www.sew.unisg.ch } \\ \\ \text { Prof. Conny Wunsch } \\ \text { VU University Amsterdam } \\ \text { Department of Economics } \\ \text { De Boelelaan 1105, 1081 HV Amsterdam } \\ \text { The Netherlands } \\ \text { Email: c.wunsch@vu.nl }\end{array}$

\footnotetext{
${ }^{1}$ Michael Lechner and Conny Wunsch are also affiliated with CESIfo, Munich, and IZA, Bonn. Michael Lechner has further affiliations with CEPR and PSI, London, and IAB, Nuremberg. Conny Wunsch is also affiliated with the Tinbergen Institute, Amsterdam. This project received financial support from the Institut für Arbeitsmarkt und Berufsforschung, IAB, Nuremberg (contract 8104), and from the St. Gallen Research Center for Aging, Welfare, and Labor Market Analysis (SCALA). We are grateful to the staff of the Forschungsdatenzentrum (FDZ) of the Federal Employment Office (BA) in Nuremberg, where most of the estimations were conducted, who provided skillful assistance. Martin Huber appreciates the hospitality of the Economics Department of Harvard University which he was visiting while writing parts of this paper.
} 


\begin{abstract}
In this paper, we assess the impact of firms introducing part-time work schemes for gradual labour market exit of elderly workers on their employees' labour market outcomes. The analysis is based on unique linked employer-employee data that combine high-quality survey and administrative data. Our results suggest that partial or gradual retirement options offered by firms are an important tool to alleviate the negative effects of low labour market attachment of elderly workers in ageing societies. When combined with financial incentives to hire unemployed or young jobseekers as replacement, they seem to be particularly beneficial, especially when labour market conditions are difficult. Under such circumstances, they can even have positive spill-over effects on younger workers. Firms should thus be encouraged to offer such schemes.
\end{abstract}

\title{
Key-Words
}

Part-time work, elderly employees, treatment effects, matching.

\section{JEL Classification:}

$\mathrm{J} 14, \mathrm{~J} 26, \mathrm{C} 21$. 


\section{$1 \quad$ Introduction}

The low labour market attachment of the elderly has far-reaching consequences for the sustainability of the public welfare system in general and the pension system in particular, as well as important implications for future labour supply in ageing societies. Despite increasing longevity, the average effective age at which older workers withdraw from the labour force has declined in almost all OECD countries since the 1970s (OECD, 2009). Even though this trend has been slightly reversed since the turn of the millennium, the effective retirement ages in all but two OECD countries remain substantially lower than in the 1960s and 1970s. For Germany, Börsch-Supan and Jürges (2011) report that the labour force participation of elderly men aged 60 to 64 has dropped from more than 80\% in 1966 to less than 35\% in 1980s and 1990s. Since about the year 2000, the participation rate has been increasing again, arguably as a response to a sequence of cost cutting reforms after 1992, but it was still just over $40 \%$ in 2005. Also female labour force participation in this age group has dropped sharply in the 1970s and only started to recover in the mid-1990s, reaching approximately 25\% in 2005.

Germany introduced partial and gradual retirement options in 1996 under the name of part-time work for elderly employees (henceforth PWE). It was intended as a means to smooth the transition from work life to retirement for individuals of age 55 and older. ${ }^{1}$ Employees and employers were given the choice between a part-time work schedule during the entire PWE period, and a full-time work schedule in the first half and a leave of absence in the second half of the PWE period, which is called the block model.

Over the entire PWE period, the employers were obliged to pay $50 \%$ of the gross wage. However, if the employer filled the vacancies created by PWE with unemployed or young job seekers, Germany's Federal Employment Agency (FEA) provided a supplement

Indeed, multiple surveys that have been conducted in various countries suggest that workers have an interest in reducing their working hours as they get older, see for instance Abraham and Houseman (2004) and Drago, Wooden, and Black (2009). 
payment such that employees in PWE effectively received $70 \%$ of their prior net salary and 90\% of their pension contribution. The aim of PWE was to decrease costs in the public pension and unemployment schemes through an increase in the labour force attachment of elderly workers that would have otherwise withdrawn from work life completely via unemployment and/or early retirement. The political discussion of PWE has been highly controversial, despite a legal revision in 2004 that reduced the generosity of supplement payments. Critics argue that the block model, which accounts for the vast majority of PWE agreements, has a similar character as "regular" early retirement schemes (see the discussion in Brussig, Knuth, and Wojtkowski, 2009) and that PWE, in contrast to its initial intention, creates unjustifiable public costs through the supplement payments of the FEA.

Motivated by the challenges of the negative effects of low labour market attachment of elderly workers in ageing societies and the ambiguity of the merits of PWE in the political discussion, this paper investigates the effects of the availability of PWE in German firms on the labour market outcomes of their employees. Most of the existing literature has focused on studying the determinants of partial retirement (e.g. Gustman and Steinmeier, 1984; Honig and Hanoch, 1985; Ruhm, 1990; Hurd and McGarry, 1993; Haider and Loughran, 2001; Hutchens, 2003; Even and Macpherson, 2004; Hutchens and Grace-Martin, 2006; Hutchens and Chen, 2007; Robinson and Clark, 2010). Comparably few studies investigate the effect of these schemes on the age at which workers completely withdraw from the labour market. Using the 2006 Portuguese Labour Force Survey and a hazard model, Machado and Portela (2012), for example, investigate the effect of a voluntary reduction in hours of work on the timing of full retirement. The authors find that reductions are associated with earlier retirement in their data and conclude that reducing hours of work appears to signal the desire to retire sooner rather than to remain in the labour market (at reduced hours). 
This paper contributes to the existing literature in several dimensions. Firstly, we not only investigate how the availability of PWE affects labour market participation, but also consider other outcomes of interest. We study the effects on employment and tenure as alternative measures of labour market attachment and worker retention. Additionally, we investigate the effects on unemployment as alternative pathways to (early) retirement which may be substituted for PWE. Our findings can therefore serve as inputs to a cost-benefit analysis of PWE in terms of public costs.

Secondly, we analyse effect heterogeneity with respect to regions with different labour market conditions and gender. Thirdly, we study potential spill-over effects on workers in the same firm that are not (yet) eligible for PWE. Such effects are likely to exist in Germany due to the financial incentives to hire unemployed or young jobseekers as replacement for employees who retire via PWE. This institutional feature also distinguishes our study from most of the existing literature which considers rather informal arrangements of partial retirement between employers and employees which do not involve public action, see for instance Gustman and Steinmeier (1984), Honig and Hanoch (1985), and Robinson and Clark (2010). Investigating the role of these incentives appears important in order to judge the scope policy makers have in influencing the labour market attachment of elderly workers and whether the results justify public intervention.

Finally, relative to the existing literature, we also make some methodological improvements. We exploit unique linked employer-employee data that combine high-quality survey and administrative data. These data allow us to follow individual labour market outcomes for up to 6.5 years, such that both short and longer-term effects can be assessed. We explicitly address the selection problems involved in the estimation of the effects of PWE on workers' labour market outcomes. The richness of the data allows us to plausibly control for employers' selection into offering PWE. Moreover, in addition to conditioning on a compre- 
hensive set of observed characteristics, we use an empirical design that also controls for unobserved time-constant confounders. Also in contrast to much of the literature, we use rather flexible econometric methods, namely semiparametric radius matching on the propensity score as proposed in Lechner, Miquel, and Wunsch (2011) and analyzed in terms of finite sample properties in Huber, Lechner, and Wunsch (2013). Contrary to parametric estimators, these robust methods have the advantage that they do not rely on tight functional form assumptions that are likely to be violated in real world applications, and they allow for effect heterogeneity.

We find that PWE does not affect the time at which elderly workers withdraw from the labour market. Instead, the availability of PWE reduces unemployment on the way towards (early) retirement. For East Germany, in contrast to West Germany, we find positive effects on employment and tenure as measures of labour market attachment and worker retention by firms. Moreover, in East Germany there are also positive spill-over effects on younger females. They benefit from increased employment and job stability as well as from reduced unemployment. This effect is likely due to the financial incentives to hire unemployed or young jobseekers as replacement for retiring workers. These findings suggest that partial or gradual retirement options offered by firms are an important tool to alleviate the negative effects of low labour market attachment of elderly workers in ageing societies, especially when combined with financial incentives to hire new workers.

The remainder of the paper is organized as follows: Section 2 provides background information on PWE in Germany. In Section 3, we introduce the database and define the sample used in the estimation. Section 4 presents descriptive statistics. Identification and estimation are outlined in Section 5. Section 6 discusses the effect estimates for the various groups defined by age, gender, and region. Section 7 concludes. Appendix A provides the specifications and results of the estimations of the various propensity scores. 


\section{Background information on part-time employment for elderly in Germany}

\section{$2.1 \quad$ Institutional background}

Partial or gradual retirement options were introduced in Germany in 1996. Employers and employees could choose between two options (see German Federal Employment Agency 2003): a part-time work schedule during the entire PWE period, and the so-called block model which comprises a full-time work schedule in the first half and a leave of absence in the second half. Over the entire PWE period, employers were required to pay $50 \%$ of the gross wage. If the vacancies created by PWE were filled with unemployed or young job seekers, Germany's Federal Employment Agency (FEA) provided a supplement payment such that employees in PWE effectively received 70\% of their prior net salary and 90\% of their pension contribution. Smaller companies with up to 50 employees were also allowed to hire apprentices instead of unemployed and/or young job seekers. To be eligible for the supplement, which was granted for at most 6 years (even if the PWE agreement covered a longer period), employees had to be 55 or older and had to work for at least 18 hours per week after reducing their working time by half. In 2000, eligibility was extended to individuals in part-time employment (even before switching into PWE).

In 2004, the PWE regulations were revised in the course of the so-called Hartz III legislation that reduced the generosity of the FEA-sponsored components (see German Federal Employment Agency, 2008). Firstly, for all PWE agreements starting on July 1, 2004 or later, a 20\% wage supplement to the PWE gross salary (50\% of the prior full time gross salary) was granted, however, excluding single or irregular payments. This could generally entail a net salary lower than $70 \%$ of the prior full time net salary. Secondly, the pension contributions were reduced. Thirdly, for the block model, employers were obliged to insure against loss in case of bankruptcy. Finally, by 2010, the entitlement to FEA supplements for new PWE agreements expired altogether implying that no new supplement payments were granted from 
2010. However, the PWE Act remains a valid legal framework for employers and employees, even if FEA sponsoring does no longer apply to new agreements.

\section{$2.2 \quad$ Utilization of PWE}

As shown in Figure 2.1, the utilization of PWE increased steadily in the 10 years after its introduction in 1996, reaching an annual average stock of almost 530,000 elderly workers in 2006. In the subsequent two years, PWE utilization remained quite stable. According to Brussig, Knuth, and Wojtkowski (2009), almost one in five employees aged 55 to 64 was in PWE in 2007 when considering total employment subject to obligatory social security contributions in this age group. In 2009, PWE experienced a sharp rise to more than 672,000 workers, very likely as a reaction to the economic crisis. Disentangling the stock by gender and region shows that males in West Germany accounted for 48\%, females in West Germany for 31\%, males in East Germany for 8\%, and females in East Germany for 13\% of PWE in 2009 according to the German Pension Insurance Fund (2012).

Figure 2.1: Annual average stock of total and FEA-sponsored PWE

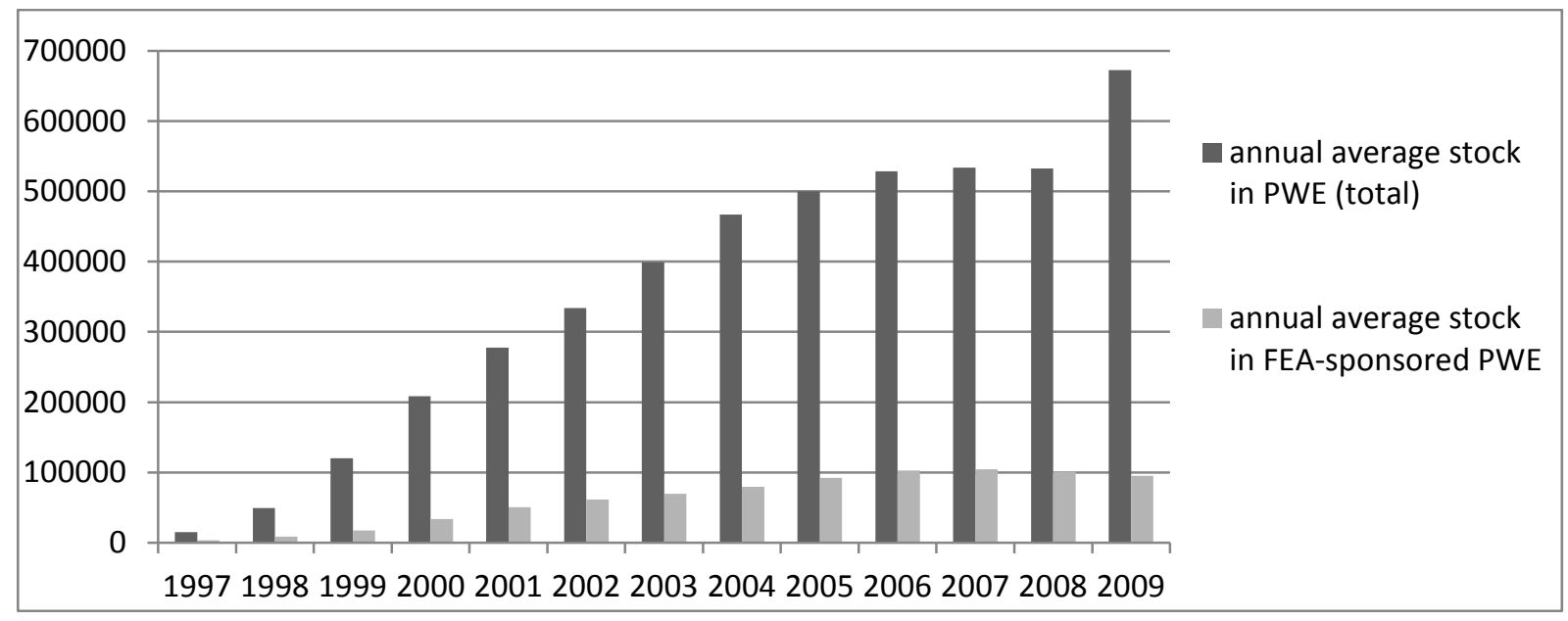

Sources: Statistics of the German Pension Insurance Fund (http://www.deutsche-rentenversicherung.de, 2012) and of the German Federal Employment Agency (http://statistik.arbeitsagentur.de, 2012).

Interestingly, only a minor part of total PWE in any given period was supported by the FEA. After a continuous rise it passed 100,000 beneficiaries in 2006 and has been declining 
slowly ever since 2008. Note that the statistic only considers cases that received FEA transfers in the respective year, irrespective of the total time frame of the PWE agreement. For the block model, this implies that the individuals only enter these statistics during their leave of absence, i.e., in the second half of the PWE, as FEA payments only start after the full-time work phase. Disentangling the shares of the two PWE models, namely part-time work over the entire time frame versus the block model, reveals that the latter is by far the more popular option and has become more important over time. Already in 2005, 84.6\% of all FEA-sponsored PWE agreements were based on the block model, and its share increased to 89.1\% (90.2\%) in 2008 (2011) (see German Federal Employment Agency, 2012).

Figure 2.2 shows that the costs of FEA-sponsoring have risen dramatically since the introduction of PWE, therefore causing much controversy in political and public debates in Germany. Expenditures climbed from just 10.6 million Euros in 1997 for 3,286 cases to a staggering 1.38 billion in 2007 when FEA-sponsored PWE reached its peak (104,350 cases). In 2010, PWE still accounted for 1.34 billion or roughly 3\% of the FEA's total expenditures.

Figure 2.2: Annual PWE-related expenditures of the Federal Employment Agency

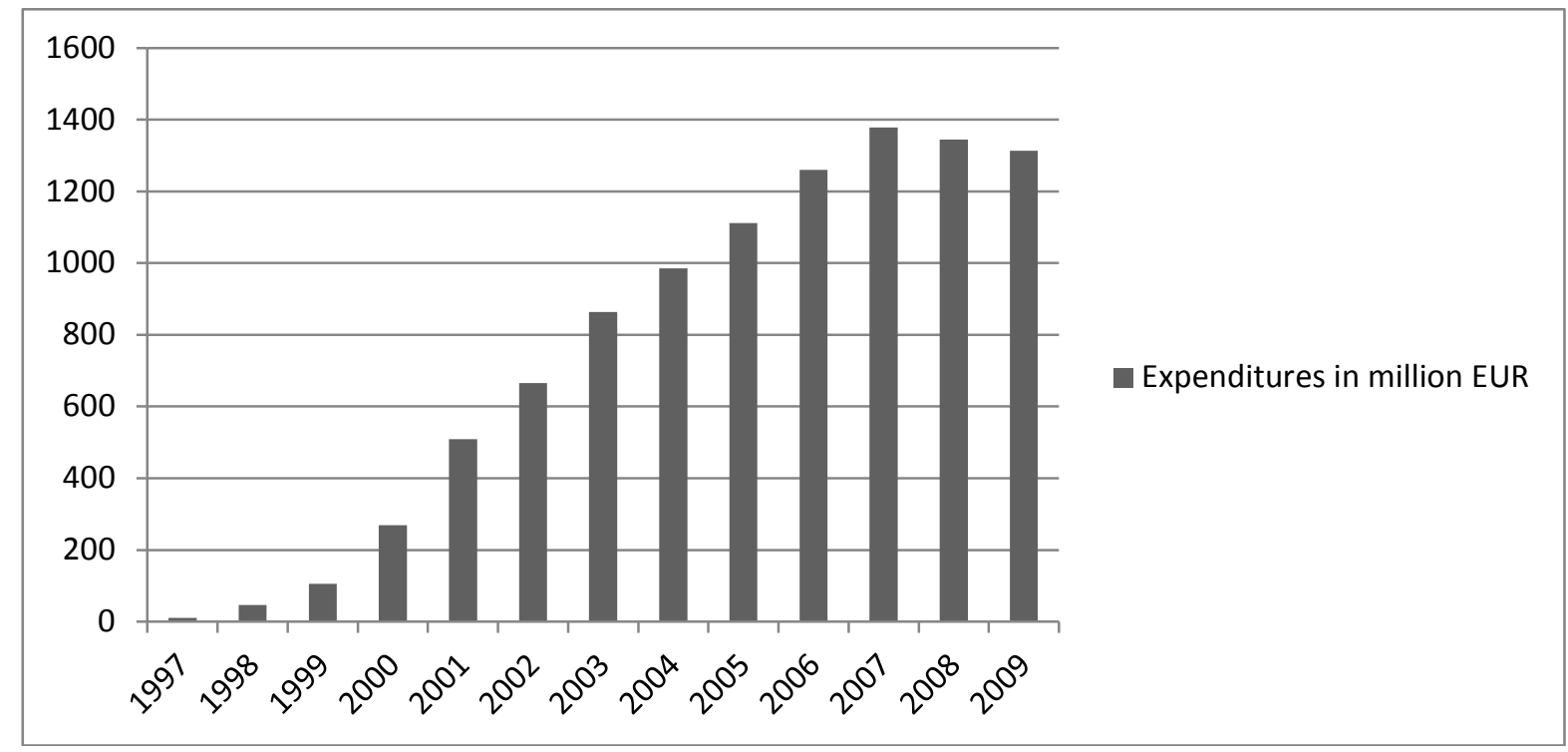

Sources: Statistics of the German Federal Employment Agency (http://statistik.arbeitsagentur.de, 2012).. 


\section{Data and definition of the sample}

\subsection{Data}

Our empirical analysis relies on unique linked employer-employee data that combine different administrative and survey data sets from the FEA's Institute of Employment Research (IAB). The data is based on the IAB Establishment Panel, which is a representative survey of German establishments. It covers a broad spectrum of firm level information including firm size, industry, legal form, biographical data, structure of the work force (e.g. education, occupation, share of males/females), employee turnover, vacancies and labour demand, working hours, human resource policies (e.g. flexible work time, inclination to recruit older workers) and training activities, financial revenues and profits, investment activities, usage rate, technological and organizational factors, and use of financial support or subsidies, among many others. The survey was first conducted in 1993 and is annually repeated. It is an unbalanced panel due to attrition and the inclusion of new companies over time. Currently it covers almost 16,000 firms.

The information from the EP has been linked to the so-called IAB Establishment History Panel which includes a rich set of aggregate information on the firm's employees. The variables describe the composition of a firm's work force, for example in terms of age, education, tenure, and earnings. They are based on the employees' social insurance records and are constructed, for each year, from the cross section of all workers employed in the firm on June 30.

For the firms in our sample, which is described in more detail below, the social insurance records of their employees with full employment, unemployment and earnings histories and a rich set of personal characteristics for the years 1990-2008 have been merged to the firm data. These data have been used, for example, by Wunsch and Lechner (2008), Biewen et al. (2013), Wunsch (2013), and Lechner and Wunsch (2013). Finally, the data base also con- 
tains a rich set of regional characteristics such as the federal state, urbanization, and local labour market conditions that have been linked via county identifiers from regional statistics.

\subsection{Sample and treatment definition}

Our empirical analysis is based on the firms included in the IAB Establishment Panel in 2000. As described in more detail below, the design of our study also requires that we observe firms in the 1999 and 2002 waves of the survey. We furthermore exclude all firms with less than 100 or more than 1000 employees in the year 2000 to increase homogeneity and avoid common support problems. The latter arise if for some firms that offer PWE no comparable (in terms of observed characteristics) firms that do not offer PWE can be found. In particular, small firms are rarely offering PWE and, therefore, a size of less than 100 employees would almost perfectly predict selection into treatment. Furthermore, firms that neither have a collective wage agreement, nor tie pay to collective agreements were discarded due to similar common support issues. For similar reasons, we exclude firms in specific sectors, in particular agriculture, forestry, mining, power/water supply, children's/retirement homes, laundry/cleaning services, grooming, rental activities (e.g. cars), public administration, and social insurance. Firm that could not be attributed to any industry are deleted as well. Thus, the sample is restricted to private companies that are representative for firms in the manufacturing and service sectors.

Information about PWE comes from two sources. Firstly, the 1999 and 2002 waves of the firm survey include a question whether the firms offers PWE. Secondly, the social insurance records of the employees indicate whether there is any worker on a PWE contract. For identification we will exploit the introduction of PWE in some firms between 2000 and 2002. Therefore, our baseline sample consists of firms that do not offer PWE in 1999 and 2000 (measured in the 1999 survey and the administrative data from 1999 and 2000). Treatment status is defined based on the availability of PWE in 2002: The treated pool consists of all 
firms that have switched to offering PWE according to the survey data, while those not offering PWE in 2002 according to both the survey data and to the administrative data constitute the nontreated sample. The very few cases where PWE is offered according to the administrative data but not according to the survey data are discarded from our sample.

In our analysis, we focus on the effects of offering PWE on the firms' work force in the year 2000. Thus, our estimation sample consists of the workers who are employed by the sampled firms in June 2000 with at least three years of tenure. The conditions prevents that identification is jeopardized, for example, by employees entering a firm in reaction to the (expected) introduction of PWE. Furthermore, we select only workers of age 31 to 60 years (June 2000). This condition ensures that workers are sufficiently removed from educational choices and statutory retirement age (65).

Table 3.1: Number of firms and individuals per stratum

\begin{tabular}{l|ccc|ccc|ccc|ccc}
\hline \hline & \multicolumn{4}{|c|}{ West } & \multicolumn{4}{c}{ East } \\
Age & \multicolumn{3}{|c|}{ Males } & \multicolumn{3}{c|}{ Females } & \multicolumn{4}{c}{ Males } & \multicolumn{3}{c}{ Females } \\
\hline Firms & $17-40$ & $41-50$ & $51-60$ & $31-40$ & $41-50$ & $51-60$ & $31-40$ & $41-50$ & 51 plus & $31-40$ & $41-50$ & $51-60$ \\
\hline Individuals & 4098 & 4269 & 176 & 178 & 178 & 174 & 166 & 167 & 171 & 172 & 201 & 182 \\
\hline
\end{tabular}

We conduct our evaluation within 12 distinct strata. They are defined by region (West and East Germany) to account for differences in selection into treatment, as well as age groups (elderly: 51-60, intermediate: 41-50, and young: 31-40) and gender, to account for the possibility of heterogeneous treatment effects. Table 3.1 summarizes the number of observations (firms and individuals) that are available in each of the 12 strata.

\section{Descriptive statistics}

This section presents descriptive statistics for the key group of elderly workers (aged 51-60) and their employers. In Table 4.1, we present characteristics of the firms in which the 
elderly workers were employed in June 2000, separately by PWE status, gender, and region. Table 4.2 displays the characteristics of employees in those groups. ${ }^{2}$

Table 4.1 shows that the introduction of PWE is selective with respect to a range of firm characteristics. In particular, establishments providing PWE are on average substantially larger and pay higher wages than those which do not. Moreover, they differ considerably from non-providers of PWE in terms of the distribution of industries. Organizational characteristics also seem to matter. Foreign-owned firms or companies that tie wages to a collective agreement are less likely to offer PWE, while firms with a works council or profit sharing arrangement are more likely to do so. The incidence of recent corporate reorganizations is also related to the treatment, however, in opposite directions for West and East Germany. A further important dimension concerns staff-related issues such as difficulties in hiring or retaining employees, because PWE could potentially be used to alleviate such problems. Indeed, the data suggest that firms reporting searching for employees and having trouble in finding skilled personnel are more likely to offer PWE, arguably to prevent experienced elderly employees from leaving the firm too early.

2 Information on the younger groups that are also considered in the econometric analysis (aged 41-50 and 3140 , respectively) is available from the authors upon request. Also, due to the very large number of variables in the data (several hundred) we abstain from presenting statistics on all variables. They are available on request. The information available in administrative data is well documented in Wunsch and Lechner (2008) and Lechner and Wunsch (2013). For a detailed documentation of the variables available in the IAB Establishment Panel see http://fdz.iab.de/de/FDZ_Establishment_Data/IAB_Establishment_Panel/IAB_ Establishment_Panel_Working_Tools.aspx, for those in the IAB Establishment History Panel see http://fdz.iab.de/de/FDZ_Establishment_Data/Establishment_History_Panel/Establishment_History_Panel_ Working_Tools.aspx. 
Table 4.1: Mean characteristics of firms of elderly workers, by gender and region

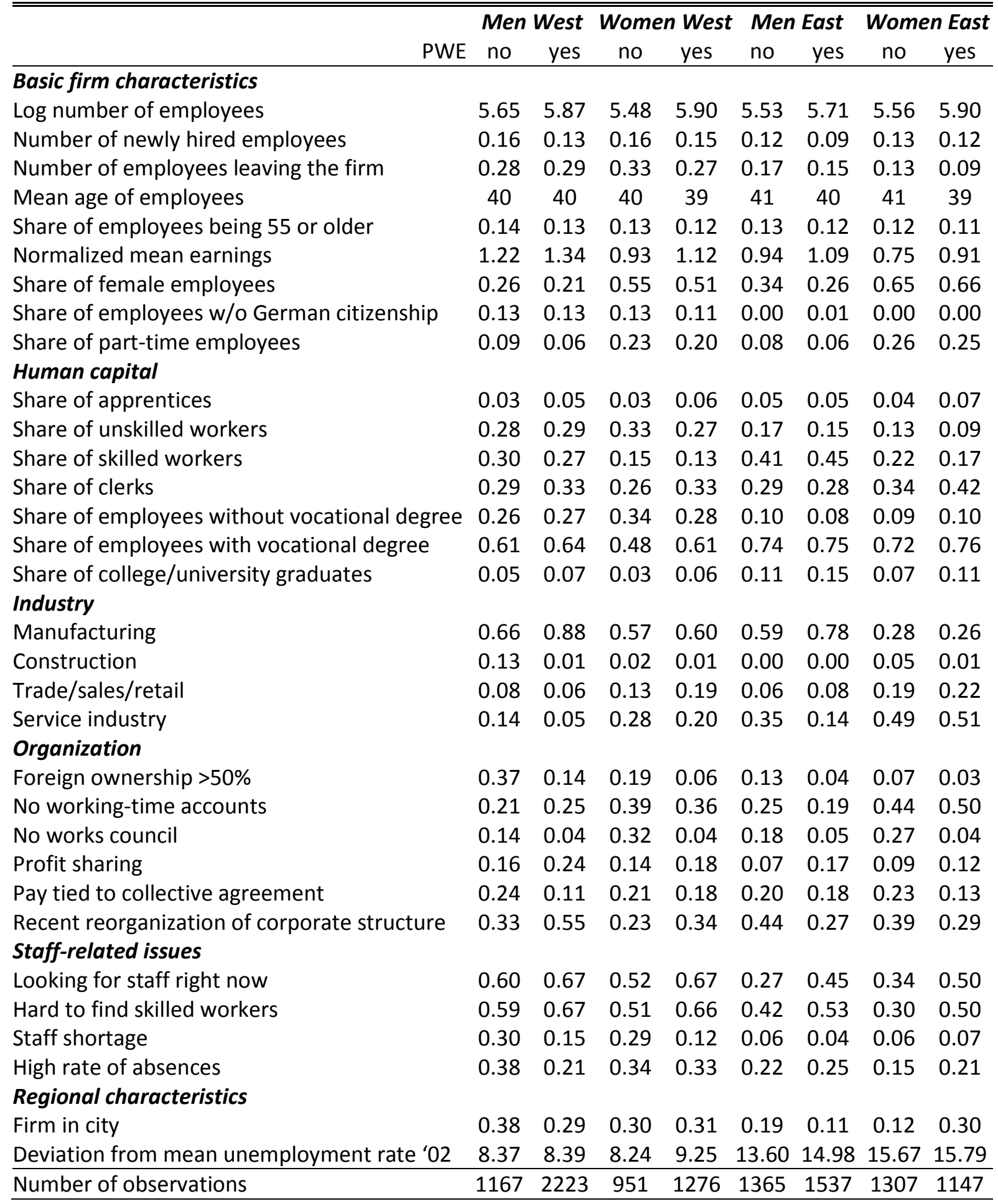

Note: $\quad$ All variables are measured in 2000 or relative to June 30, 2000. 
Table 4.2: Mean characteristics of elderly workers, by gender and region

\begin{tabular}{|c|c|c|c|c|c|c|c|c|}
\hline & \multicolumn{2}{|c|}{ Men West } & \multicolumn{2}{|c|}{ Women West } & \multicolumn{2}{|c|}{ t Men East } & \multicolumn{2}{|c|}{ Women East } \\
\hline PWE & no & yes & no & yes & no & yes & no & yes \\
\hline Age & 55.2 & 55.2 & 55.1 & 54.6 & 55.5 & 55.3 & 54.8 & 54.8 \\
\hline No vocational degree & 0.18 & 0.20 & 0.46 & 0.38 & 0.05 & 0.04 & 0.08 & 0.06 \\
\hline Vocational degree & 0.68 & 0.71 & 0.42 & 0.56 & 0.72 & 0.72 & 0.76 & 0.82 \\
\hline College/university degree & 0.06 & 0.05 & 0.01 & 0.01 & 0.19 & 0.23 & 0.07 & 0.08 \\
\hline Tenure in years & 3.49 & 3.34 & 3.24 & 3.39 & 2.66 & 2.82 & 2.64 & 2.79 \\
\hline Share employed in 2 years before 2000 & 1.00 & 1.00 & 0.86 & 0.94 & 0.36 & 0.48 & 0.36 & 0.38 \\
\hline Share unemployed in 2 years before 2000 & 0.00 & 0.00 & 0.03 & 0.01 & 0.02 & 0.01 & 0.06 & 0.03 \\
\hline Share out of labour force in 2 years before 2000 & 0.00 & 0.00 & 0.12 & 0.05 & 0.62 & 0.51 & 0.58 & 0.59 \\
\hline Gross earnings per month in 2000 & 3060 & 3240 & 1760 & 2080 & 2180 & 2480 & 1660 & 1920 \\
\hline Unskilled worker & 0.24 & 0.26 & 0.42 & 0.32 & 0.16 & 0.13 & 0.14 & 0.08 \\
\hline Skilled worker & 0.39 & 0.34 & 0.06 & 0.01 & 0.50 & 0.53 & 0.12 & 0.09 \\
\hline Clerk & 0.37 & 0.40 & 0.25 & 0.30 & 0.34 & 0.34 & 0.49 & 0.54 \\
\hline Job in engineering & 0.30 & 0.33 & 0.03 & 0.03 & 0.27 & 0.36 & 0.04 & 0.07 \\
\hline Job in construction & 0.09 & 0.03 & 0.02 & 0.02 & 0.00 & 0.00 & 0.00 & 0.00 \\
\hline Job in manufacturing & 0.15 & 0.26 & 0.20 & 0.16 & 0.16 & 0.21 & 0.06 & 0.06 \\
\hline High-skilled job in services & 0.27 & 0.24 & 0.37 & 0.49 & 0.28 & 0.22 & 0.55 & 0.69 \\
\hline Low-skilled job in services & 0.09 & 0.07 & 0.19 & 0.12 & 0.18 & 0.12 & 0.21 & 0.13 \\
\hline Other job & 0.10 & 0.08 & 0.19 & 0.18 & 0.10 & 0.06 & 0.14 & 0.04 \\
\hline No German citizenship & 0.12 & 0.14 & 0.11 & 0.11 & 0.00 & 0.00 & 0.00 & 0.00 \\
\hline Number of observations & 1167 & 2223 & 951 & 1276 & 1365 & 1537 & 1307 & 1147 \\
\hline
\end{tabular}

Note: $\quad$ All variables are measured in 2000 or relative to June 30, 2000.

Table 4.2 indicates that the firms offering PWE also differ in terms of the composition of their work force. Their employees appear to have on average somewhat more favourable labour market histories. For example, the proportion of time in employment prior to the treatment period is higher (apart from West German men, who were fully employed in any case), while among West German women and East German men, the time out of labour force is lower. Furthermore, the average earnings of elderly employees in firms with PWE are somewhat higher, which is in line with the higher average earnings among firms with PWE in general. Finally, the composition of jobs differs substantially across elderly workers in firms with and without PWE, which appears intuitive given the differences in the distribution of industries mentioned before. 


\section{Empirical strategy}

\subsection{Identification}

Identification of the effect of PWE requires solving two selection problems. Firstly, workers self-select into PWE. Gustman and Steinmeier (1984), for example, find using the Retirement History Study (RHS) on men aged 58 to 63 provided by the US Social Security Administration, that partial retirement varies systematically with individual characteristics such as age, health, family status as well as pension coverage, mandatory retirement provisions, and wage offers in the main and partial-retirement jobs. Similarly, Honig, and Hanoch (1985) use the same data source and identify health, age, education, expected social security income, nonwage income, self-employment, labour force experience, and pension coverage as key determinants of retirement, partial retirement, and full employment. ${ }^{3}$ More recently, Robinson and Clark (2010) combined the HRS with the Rand HRS database to estimate the effect of retiree health insurance on the retirement decision by means of a Cox proportional hazard model and propensity score matching. Insurance is found to increase the likelihood to disengage from the job considerably. Many of these variables, especially health and pension coverage are unobserved in most data sets.

We tackle the problem of self-selection of workers into PWE as follows: Firstly, we estimate a causal parameter similar to an intention-to-treat effect. Specifically, we estimate the effect of the availability of PWE in a firm rather than take-up of PWE by its employees. We consider this parameter the most interesting one as it gives the effect of introducing the PWE at the firm level. Secondly, we consider workers who are employed in firms that do not offer PWE initially and then exploit the introduction of PWE by some but not by all of those firms. Thirdly, we require that all workers have been with the firm for at least three years by

Furthermore, Kim and DeVaney (2005) estimate a multinomial logit based on the RHS. In line with previous findings, their results suggest that the more educated and self-employed more likely choose partial retirement over full-time work, while those with more financial assets, pensions, health insurance, poor health, and less education have an increased probability to fully retire. Also see Ruhm (1990) and Haider and Loughran (2001). 
the time PWE is introduced to ensure that workers did not self-select into firms in anticipation of the introduction of PWE.

The second selection problem occurs because firms select into offering PWE. Hutchens and Grace-Martin (2006) address this issue using the US Health and Retirement Study (HRS) and conclude that phased retirement is more likely available in firms with flexible work hours, part-time employment, and job sharing. ${ }^{4}$ This is in line with Hurd and McGarry (1993), who find that particular job characteristics such as the flexibility to reduce hours or move to a less demanding job increase the prospective retirement age. ${ }^{5}$ Again using the HRS, Even and Macpherson (2004) consider both firm- and individual-level selection into partial retirement. Their results suggest that firms providing pension plans are less willing to allow workers to cut hours and that (in line with the studies mentioned before) pension-covered workers are less likely to switch to part-time employment and more likely to switch to full retirement. The latter is true even conditional on the original employer's willingness to allow a reduction in work hours and various firm and worker characteristics. Hutchens and Chen (2007) combine the HRS with a representative US employer survey conducted in 2001 and 2002 and confirm previous findings that the opportunity of partial retirement depends on both employer and employee characteristics (e.g., whether the company is public or private, worker's age, defined benefit pension plans, and unionization). Furthermore, Hutchens (2003) finds that firm size and growth, as well as the composition of the work force in terms of age, gender, and tenure is correlated with the likelihood to offer partial retirement.

We base identification on the assumption that we observe all relevant determinants of the decision to introduce PWE that are also related to the labour market performance of the firms’ employees (so-called conditional independence assumption, CIA, see Imbens, 2004,

4 See also Hutchens (2010), who uses the same survey to investigate which types of employees have particularly good chances to be considered for phased retirement in firms offering it at all.

5 Pensions and health care insurance are further important predictors of prospective retirement, in contrast to physical and mental job requirements. 
and Imbens and Wooldridge, 2009, for an in-depth discussion). The survey and administrative data together provide detailed information on job flexibility (e.g., part-time work, flexible working times, job rotation, etc.), unionization and the presence of collective agreements, industry, firm size, firm growth, and various dimensions of the work force structure such as education, occupation, gender, age and tenure, suggesting that we can control for most of the firm-level characteristics that have been identified as being crucial in the literature. Employer pension plans play a negligible role in Germany as most pensions are coming from the public pension insurance. However, we control for other financial incentives to stay with or leave a firm such as equity and profit participation. We additionally condition on important regional characteristics such as geographic region, urbanization, and local unemployment rate, which could affect the introduction of PWE via the composition of the local labour force or firm performance while at the same time influencing individual labour market success. Finally, the rich set of employee-level characteristics provided in the administrative data allows characterizing individual selection into the firms. Workers' labour market histories play a key role in this context because they allow us to implement a design, which controls for certain potentially unobserved confounders. By considering a homogenous sample of firms initially not offering PWE and conditioning on the pre-treatment labour market outcomes of the firms' employees, time-constant unobserved factors that jointly affect the introduction of PWE and workers’ labour market outcomes are controlled for in a similar way as discussed in Huber, Lechner, and Wunsch (2011). Therefore, the CIA is more plausible than in conventional cross-sectional studies that do not make use of pre-treatment outcomes. Moreover, note that due to the requirement that all workers in our sample have been with the same firm for at least three years, our sample is extremely homogenous with respect to short- to medium-run employment histories. On top of that, we condition on 10 years of employment, unemployment, and earning histories of the employees in a detailed way. Both of this provides further support for the validity of the CIA. 


\subsection{Estimation}

We use radius matching on the propensity score to estimate the average effects of the availability of PWE on employees' labour market outcomes. Any estimator based on the CIA is built on the idea of comparing outcomes across units with and without treatment that are similar with respect to observed confounders in order to pin down the causal effect of the treatment. Propensity score matching estimators define similarity in terms of the probability to be treated conditional on the confounders. In the program evaluation literature, this conditional probability is referred to as propensity score (see Rosenbaum and Rubin, 1983). An advantage of these estimators is that they are semiparametric and therefore more robust than parametric methods, and that they allow for flexible effect heterogeneity.

We estimate the propensity score using separate probit models for each of the 12 strata (defined by age, gender, and region). This approach accounts flexibly for heterogeneity in the determinants of the decision to introduce PWE across stratum characteristics. This is important, because the distinct economic situation and workforce/industry composition in West and East Germany is likely to affect the inclination towards PWE. We condition on regional, firm level, and individual characteristics to control for the firm's selection into offering PWE and the staff's selection into the respective firms. The probit specifications are presented in Appendix A. ${ }^{6}$ The coefficients show that firm size (or variables based thereon), industry, organizational features (as recent reorganizations in the corporate structure or payment oriented towards a collective agreement) and staff-related issues (hard to find skilled workers, staff shortage, high rate of absences) are crucial predictors. Among the individual characteristics, labour market histories and job characteristics (skill level and occupation) are important covariates. Finally, regional characteristics (such as whether the firm is situated in

\footnotetext{
The specifications are the result of the methodological issues discussed in the last section as well as extensive specification tests for normality, heteroscedasticity and in particular omitted variables. The data contain hundreds of variables, a lot of them being highly correlated. We started with a parsimonious specification that included the main confounders that we identified from the literature and theoretical considerations. As a result of the omitted variables tests for all variables in the data, we occasionally added additional variables.
} 
an urban area) are related to the firm's decision to offer PWE as well. Based on the estimated propensity scores we ensure overlap of the distributions in the treated and nontreated samples by excluding treated individuals with scores higher than the maximum among the nontreated and, similarly, nontreated individuals with scores lower than the minimum among the treated.

We apply a propensity-score-matching algorithm that takes into account the methodological considerations of Lechner, Miquel, and Wunsch (2011). Compared to standard nearest-neighbour matching this procedure is more precise because it incorporates the idea of radius matching (e.g. Dehejia and Wahba, 2002). Furthermore, the algorithm uses the initial matching weights in a second step (weighted) regression adjustment, which has two advantages. Firstly, the estimator satisfies a so-called double robustness property: the estimator remains consistent if either the matching step is based on a correctly specified selection model, or the regression model is correctly specified (e.g. Rubin, 1979, Joffe, Ten Have, Feldman, and Kimmel, 2004). Secondly, the regression adjustment should reduce small sample as well as asymptotic biases of matching (see Abadie and Imbens, 2006). Huber, Lechner, and Wunsch (2013) investigate the finite sample properties of the radius-matching algorithm and find it to be highly competitive in terms of mean squared error among several classes of propensity score methods. The estimation achieves a good balancing of the covariate distributions of workers in treated and untreated firms. This hold not only for the variables directly included in the respective propensity score, but also with respect to the variables not included, in particular the large number of pre-treatment outcomes. ${ }^{7}$

Concerning inference, Abadie and Imbens (2008) show that for standard matching (i.e. based on the nearest neighbour or a fixed number of comparison observations) bootstrapbased inference is not valid. However, the matching algorithm used in our analysis is smoother than the one studied by Abadie and Imbens (2008) because it is based on a variable

7 Due to the very large number of tested variables (several hundred) we abstain from presenting the results of the balancing tests. They are available on request. 
number of comparisons and the regression adjustment. For this reason, the bootstrap is most likely a valid inference procedure in our context. However, the standard bootstrap, which randomly draws employees with replacement, may underestimate the standard errors, because the treatment is assigned at the firm level rather than among individuals. Therefore, we rely on a block bootstrap that resamples firms (rather than individuals) along with all employees therein to account for clustering at the firm level. To be more precise, inference is based on (i) (block) bootstrapping firms and individuals 499 times; (ii) computing the bootstrap t-statistics of the respective average effect in each of the samples (normalized by the estimated effect); and (iii) estimating the p-value as the share of absolute bootstrap t-statistics that are larger than the absolute t-statistic in the original sample (see for instance MacKinnon, 2006, for a discussion on bootstrapping symmetric statistics).

\section{$6 \quad$ Results}

This section presents the average effects of the availability of PWE on various individual-level outcomes of the firms' employees up to 6.5 years after treatment (in 2002). We start by investigating actual usage of PWE among employees. We then analyse various individual labour market outcomes such as employment, unemployment, time out of the labour force, and earnings. It appears particularly interesting whether the availability of PWE raises the labour force attachment of elderly cohorts. Alternatively, the results in Machado and Portela (2012) suggest that the availability of PWE may accelerate (de facto) retirement, e.g., by workers lowering their regular employment and increasing the likelihood of entering unemployment or withdrawing from the labour force. We also investigate the effects on tenure, because one motivation for firms to offer PWE might be to retain elderly workers for longer than they would do otherwise. Furthermore, a firm that offers PWE might be considered a more attractive employer by all workers, which may lead to higher average tenure in treated firms. 
The effects on employees who are not eligible for PWE are of policy relevance as well, as younger workers may be indirectly affected by changes in the labour market behaviour of the elderly. For example, the possibility for elderly workers to reduce their hours worked through PWE might influence the firms' decision to hire and retain younger workers. Therefore, we also look at the labour market outcomes of employees aged 31-40 and 41-50. ${ }^{8}$ This entails 12 different strata for which the evaluation is conducted separately, making it straightforward to elicit effect heterogeneity related to the strata characteristics.

The results presented hereafter refer to the average treatment effects (ATE) on the respective full populations, i.e., on the total of employees both in firms offering and not offering PWE. It is worth noting that the average effects on the treated (i.e., on the employees actually working in establishments with PWE), which are available from the authors upon request, are in general comparable, however, considerably less precisely estimated.

\subsection{Take-up of PWE}

The first question of interest is to which extent PWE is actually utilized if available in a firm. Figure 6.1 plots the estimated average effect of PWE availability on the cumulative utilization of PWE measured in months over a time frame of 0.5 to 6.5 years after the treatment period (2002), separately for strata consisting of elderly workers (aged 51-60 in 2000) and individuals of intermediate age (41-50 in 2000). Some of the latter also become eligible towards the end of the observation period. Cumulative PWE take-up is statistically significant on the $5 \%$ level for all elderly groups at any point in time, as indicated by the round dots in the lines indicating the effects. Furthermore, PWE take-up is generally higher in the East than in the West and the differences are particularly large among females. The cumulative time in PWE is on average more than nine months for East German women after 6.5 years, but less than half a year for their West German counterparts. Nevertheless, PWE take-up is

8 As discussed in Section 2.1, the PWE supplement payment of the FEA was conditional on hiring unemployed young jobseekers. 
economically important among all elderly groups and, as expected, much higher than in the intermediate groups, where the oldest individuals only become eligible after several years. Accordingly, cumulated PWE only starts to rise after 3 years in the intermediate groups.

Figure 6.1: ATE on cumulative PWE in months

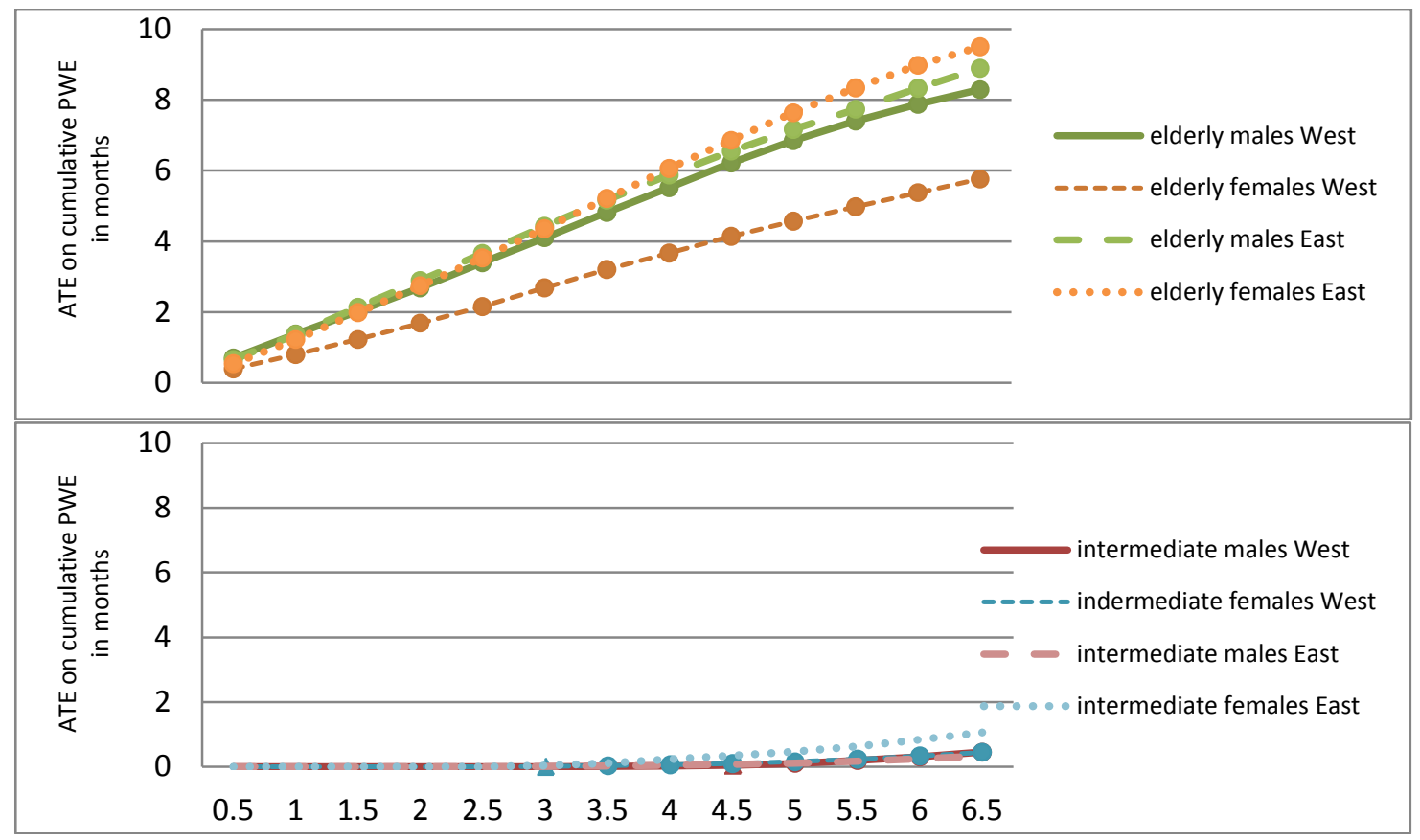

Note: $\quad$ Round dots (triangles) indicate that the effects are significant on the $5 \%(10 \%)$ level. Inference is based on 499 block bootstrap replications.

\subsection{Labour market outcomes}

The main objective of PWE is to increase the labour market attachment of elderly workers and to retain them in the firm. In Figure 6.2, we present the effects on cumulated regular employment and in Table 6.1 those on tenure in the original firm. The latter refers to the time with the firm after "treatment”, i.e. from July 2002 onwards. For elderly workers, we only find a positive impact on cumulated regular employment and tenure in East Germany. 51 to 60 year old East German men and women in firms that offer PWE accumulate, respectively, 7 and 6 more months of regular employment and stay 7.5 and 10.5 more months with the firm, which originally employed them than workers in firms that did not offer PWE in 2002. Thus, in East Germany PWE was indeed effective in increasing labour market 
attachment of elderly workers and retention rates. PWE also increases regular employment and tenure of younger females aged 31-40 in East Germany, suggesting positive spill-overs for this group in treated firms. We do not find significant employment or tenure effects for workers of any age group in West Germany, however.

Figure 6.2: ATE on cumulated regular employment in months

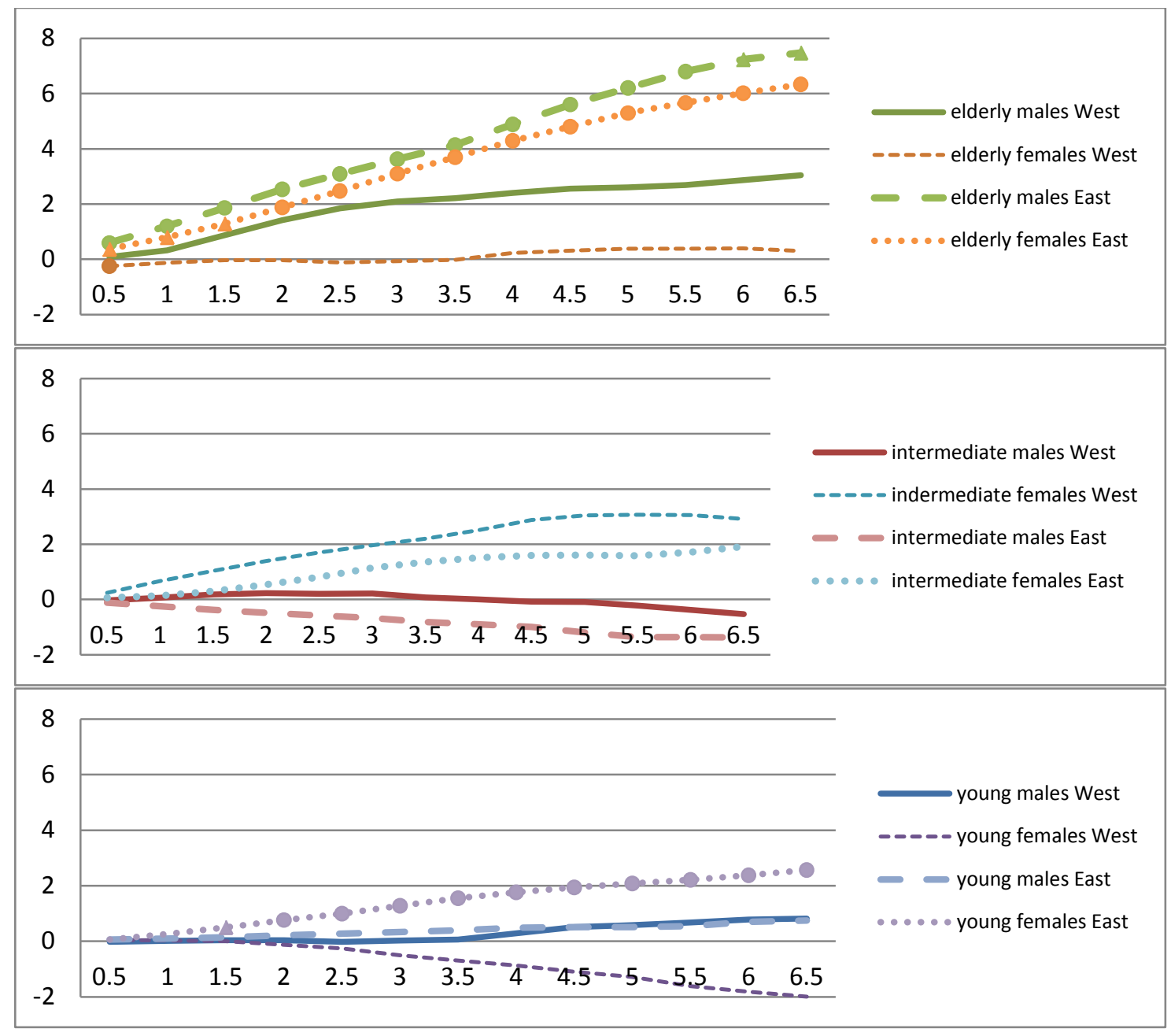

Note: $\quad$ Round dots (triangles) indicate that the effects are significant on the $5 \%(10 \%)$ level. Inference is based on 499 block bootstrap replications. 
Table 6.1: ATE on tenure in the original in firm in days

\begin{tabular}{llccc}
\hline \hline Region & Gender & Age & Effect & P-value in \% \\
\hline West & Males & $31-40$ & -91 & 72 \\
& & $41-50$ & -147 & 56 \\
& & $51-60$ & -40 & 82 \\
\hline \multirow{4}{*}{ East } & Females & $31-40$ & -204 & 30 \\
& & $41-50$ & 10 & 96 \\
& & $51-60$ & -1 & 99 \\
& Males & $31-40$ & -101 & 40 \\
& & $41-50$ & -106 & 41 \\
& & $51-60$ & 224 & 14 \\
& & $31-40$ & $298^{\star}$ & 7 \\
& & $41-50$ & 178 & 19 \\
& & $51-60$ & $320^{\star \star \star}$ & $<1$ \\
\hline
\end{tabular}

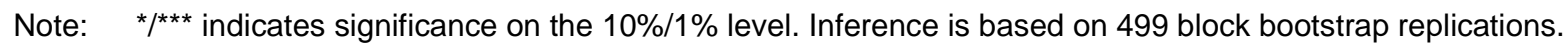
Tenure refers to the time with the firm after treatment measured from July 2002. Tenure before that is a control variable.

There is some evidence, though, that elderly workers, including West German ones, and especially men benefit from PWE financially in terms of earnings. Figure 6.3 shows the effects for elderly workers that are positive in almost all cases. With a level of 15,000 EUR after 6.5 years, they are particularly large for men, although mostly insignificant at conventional levels. Among the intermediate and younger cohorts, significant effects are only found for young females in East Germany, which is in line with their higher cumulated employment effect. 
Figure 6.3: ATE on cumulated earnings from employment in EUR

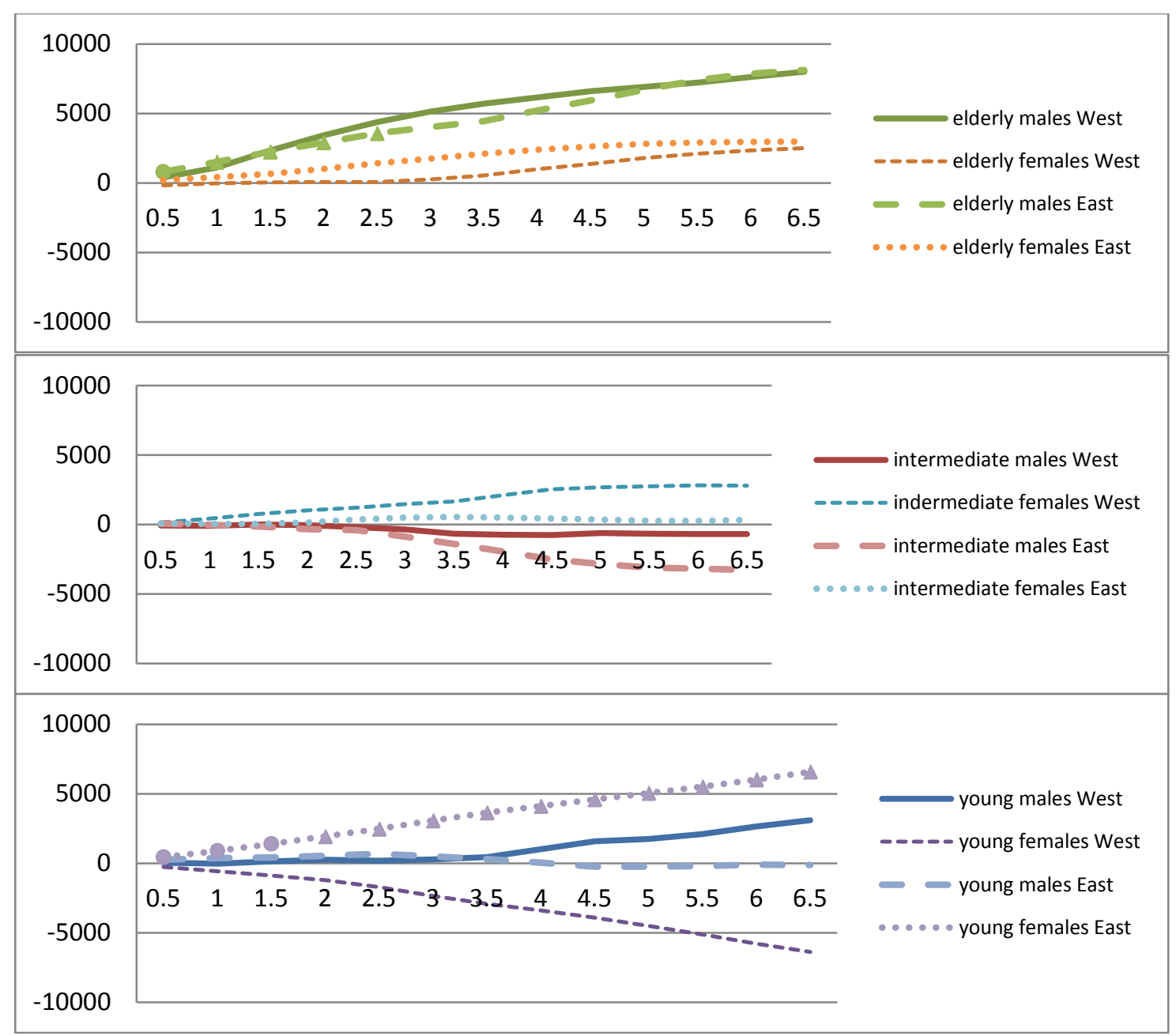

Note: Round dots (triangles) indicate that the effects are significant on the $5 \%(10 \%)$ level. Inference is based on 499 block bootstrap replications.

Another interesting policy question is whether the availability of PWE effectively reduces exits of elderly workers to unemployment. Grogger and Wunsch (2013), for example, show that, in response to particularly generous unemployment insurance payments for elderly workers in Germany, a notable share of elderly workers (voluntarily or involuntarily) exits the labour market via unemployment before early retirement options become available. PWE provides an alternative pathway for early exit from the labour market. Our results in Figure 6.4 indeed suggest that elderly workers in firms that offer PWE accumulate fewer months of unemployment. After 6.5 years, the effects are most pronounced among East German workers, with a reduction of more than 5 months, which is statistically significant on the $5 \%$ level. For West German workers the effects are somewhat smaller, but still economically important 
and mostly statistically significant on the $10 \%$ level. We also investigate the implications of the availability of PWE for younger workers. We find a significant reduction in unemployment in some of the periods, but only for women in East Germany. This suggests that the positive employment effects for younger East German women are at least partially due to new hirings that replace elderly workers who leave the firm. The effects in all remaining groups are insignificant and close to zero.

Figure 6.4: ATE on cumulated unemployment in months

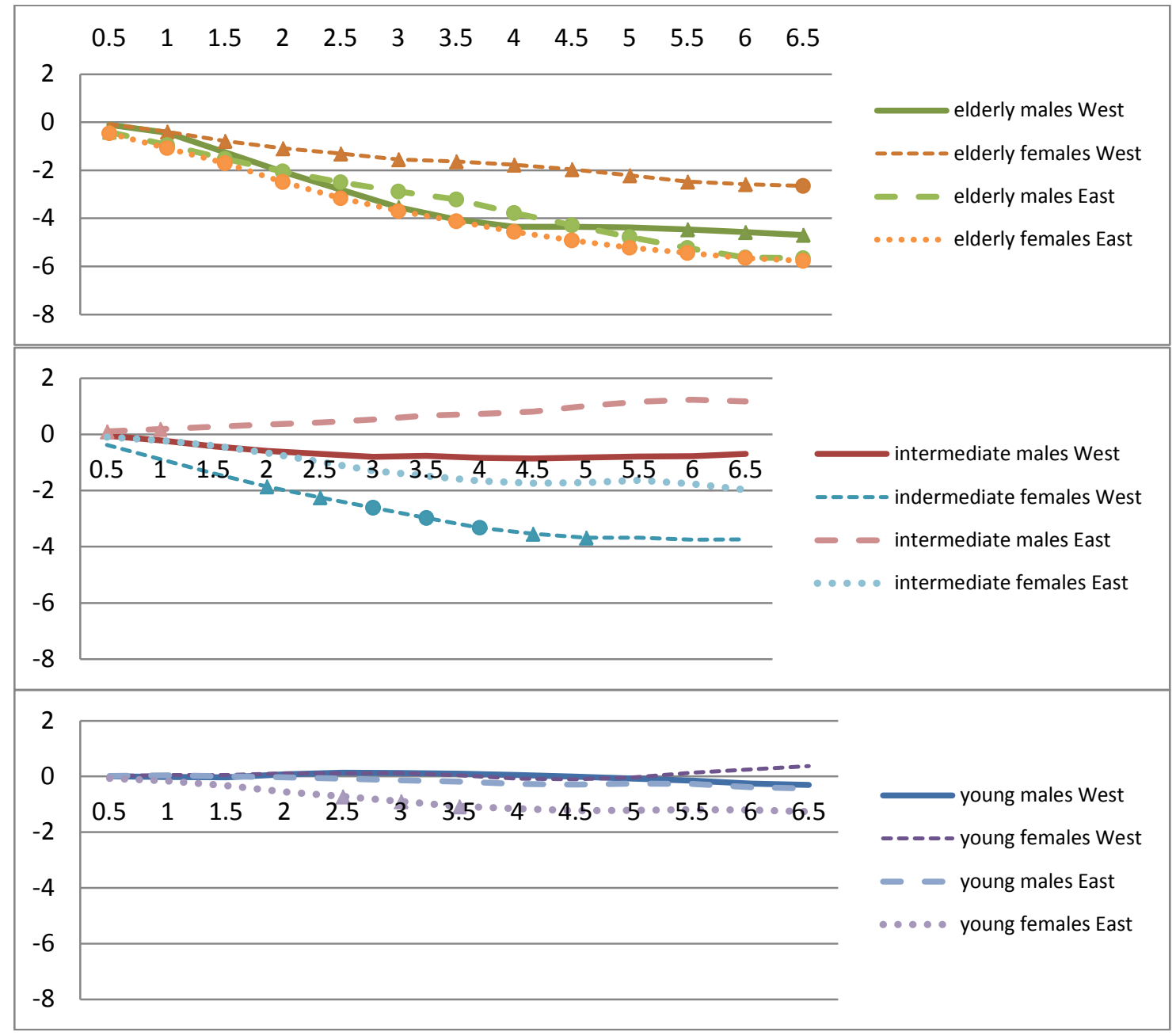

Note: Round dots (triangles) indicate that the effects are significant on the $5 \%(10 \%)$ level. Inference is based on 499 block bootstrap replications. 
Figure 6.5: ATE on cumulated time out of the labour force in months

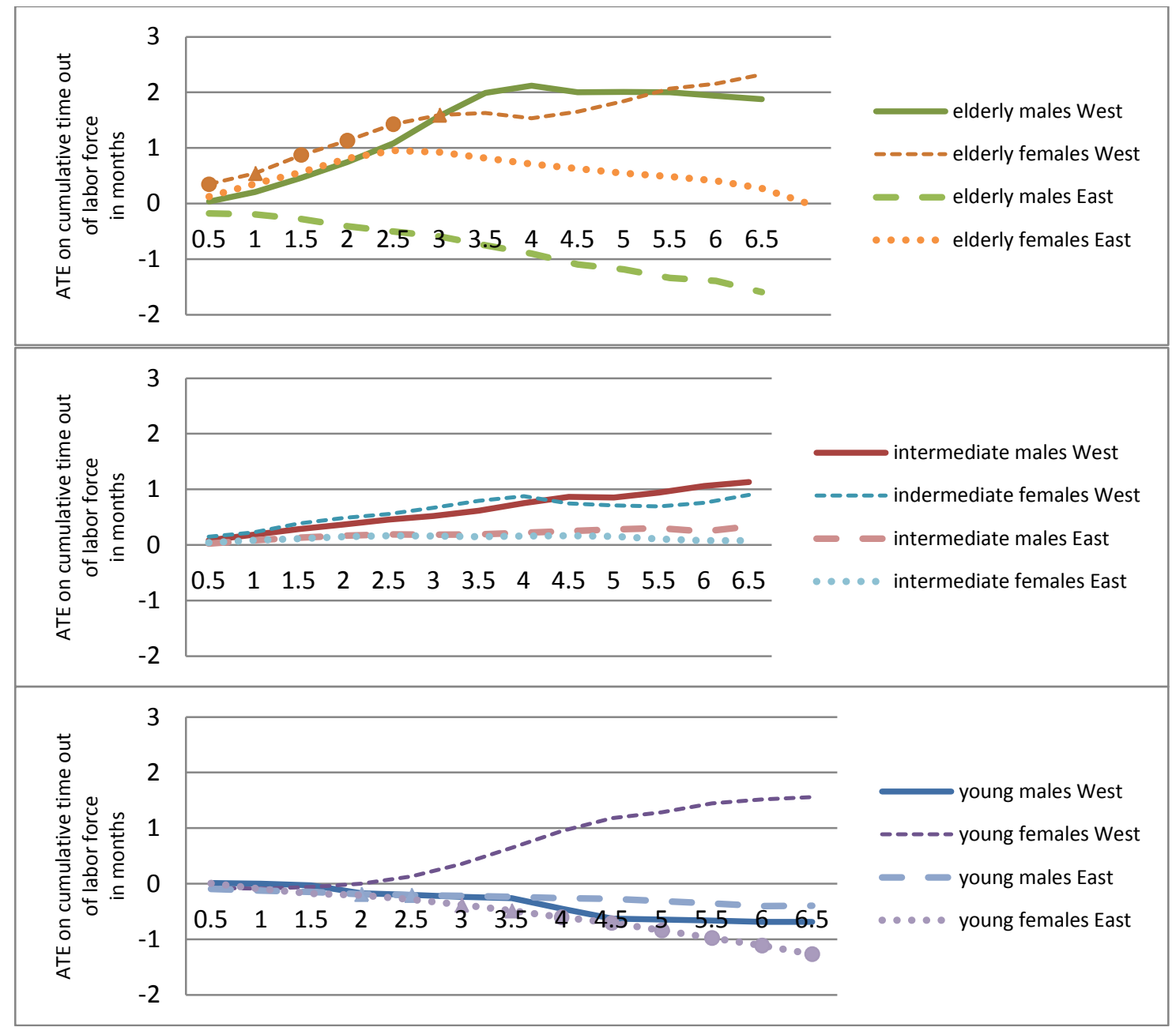

Note: Round dots (triangles) indicate that the effects are significant on the $5 \%(10 \%)$ level. Inference is based on 499 block bootstrap replications.

When considering the effects on cumulated time outside the labor force in Figure 6.5, there are few statistically significant effects. The few cases that are statistically significant are, however, economically negligible. The absence of effects on the cumulated time spent out of the labor force suggests that elderly workers in firms that offer WE withdraw from the labour market at about the same time and rate as workers in firms without PWE. Thus, this result is contrary to Machado and Portela (2012) who find that a reduction in working hours is associated with earlier full retirement. 


\section{Conclusion}

In this paper, we assess the impact of firms introducing part-time work schemes for gradual withdrawal of elderly employees from the labour market on their employees' labour market outcomes. A special feature of the German system analysed in this paper is that these schemes are combined with financial incentives to hire unemployed or young jobseekers as replacement for workers who retire via ‘part-time work for elderly employees’ (PWE).

In contrast to Machado and Portela (2012), we find that the time of complete withdrawal from the labour market is unaffected. However, the availability of PWE is beneficial in that it considerably reduces unemployment among elderly workers. The overall effects differ between East and West Germany, though. In West Germany, there are gains neither in terms of cumulated employment nor in terms of tenure in the firm. There are also no spillover effects on younger workers. PWE only changes the pathway towards retirement. The time when elderly West German employees leave their jobs is unaffected by PWE. Rather than registering as unemployed and receiving unemployment insurance or social security payment after job exit, elderly employees exit via PWE by entering the non-employment phase of the block model. During this time, they receive payments from their employer. From the perspective of the social insurance system, this is desirable because unemployment insurance and social security payments are reduced.

In East Germany, which is characterized by particularly difficult labour market conditions, PWE is more beneficial. Positive effects on net cumulated employment indicate an increase in the labour market attachment of elderly workers in addition to reduced exits via unemployment. This results in higher tax revenues and higher social insurance contributions together with lower social insurance payouts. Moreover, firms offering PWE are able to retain their elderly employees longer than firms without PWE. Most interestingly, there are also positive spill-over effects on younger East German females. They benefit from increased and 
more stable employment as well as reduced unemployment. These spill-over effects are likely to be due to the financial incentives to hire unemployed workers as replacement for employees who retire via PWE.

Our results suggest that partial or gradual retirement options offered by firms are an important tool to alleviate the negative effects of low labour market attachment of elderly workers in ageing societies. When combined with financial incentives to hire unemployed or young jobseekers, they seem to be particularly beneficial, especially when labour market conditions are difficult. Under such circumstances, they can have positive spill-over effects on younger workers. Firms should thus be encouraged to offer such schemes.

\section{Literature}

Abadie, A., and G. W. Imbens (2006): "Large Sample Properties of Matching Estimators for Average Treatment Effects", Econometrica, 74, 235-267.

Abadie, A., and G. W. Imbens (2008): "On the Failure of the Bootstrap for Matching Estimators", Econometrica, 76, 1537-1557.

Abraham, K.G., and S.N. Houseman (2004): "Work and Retirement Plans Among Older Americans", Employment Research, 11(4), 1-4.

Biewen, M, B. Fitzenberger, R. Osikominu, and M. Paul (2013): “The Effectiveness of Public Sponsored Training Revisited: The Importance of Data and Methodological Choices”, forthcoming in Journal of Labor Economics.

Börsch-Supan, A., and S. Jürges (2011): "Disability, Pension Reform and Early Retirement in Germany", NBER Working Paper, 17079.

Brussig, M., M. Knuth, and S. Wojtkowski (2009): Altersübergangs-Report, 2009-02.

Dehejia, R. H., and S. Wahba (2002): "Propensity-Score-Matching Methods for Nonexperimental Causal Studies", Review of Economics and Statistics, 84, 151-161.

Drago, R., M. Wooden, and D. Black (2009): "Who Wants and Gets Flexibility? Changing Work Hours Preferences and Life Events", Industrial \& Labor Relations Review, 62, 394-414.

Even, W.E., and D.A. Macpherson (2004): "Do Pensions Impede Phased Retirement?", IZA Discussion Paper No. 1353.

German Federal Employment Agency (2003): Altersteilzeitgesetz.

German Federal Employment Agency (2008): Altersteilzeitgesetz.

German Federal Employment Agency (2012): http://statistik.arbeitsagentur.de, July 2012. 
German Pension Insurance Fund (2012): http://www.deutsche-rentenversicherung.de, July 2012.

Grogger, J., and C. Wunsch (2013): "Unemployment Insurance and Departures from Employment: Evidence from a German Reform", Working Paper, Department of Economics, VU University Amsterdam.

Gustman, A. L., and T. L. Steinmeier (1984): "Partial Retirement and the Analysis of Retirement Behavior", Industrial and Labor Relations Review, 37, 403-415.

Haider, S., and D. Loughran, (2001): "Elderly Labor Supply: Work or Play?", RAND Working Paper DRU-2582.

Honig, M., and G. Hanoch (1985): "Partial Retirement as a Separate Mode of Retirement Behavior", The Journal of Human Resources, 20, 21-46.

Huber, M., M. Lechner, and C. Wunsch (2013): "The Performance of Estimators Based on the Propensity Score“, Journal of Econometrics, 175, 1-21.

Huber, M., M. Lechner, and C. Wunsch (2011): "Does Leaving Welfare Improve Health? Evidence for Germany", Health Economics, 20, 484-504.

Hurd, M., and K. McGarry (1993): "The relationship between job characteristics and retirement", NBER Working Paper, 4558.

Hutchens, R. (2003): The Cornell Study of Employer Phased Retirement Policies: A Report on Key Findings, School of Industrial and Labor Relations, Cornell University, Ithaca, New York.

Hutchens, R. (2010): "Worker characteristics, job characteristics, and opportunities for phased retirement", Labour Economics, 17, 1010-1021.

Hutchens, R., and J. Chen (2007): "The Role of Employers in Phased Retirement: Opportunities for Phased Retirement Among White-Collar Workers", ILR Collection Articles \& Chapters Paper 48.

Hutchens, R., and K. Grace-Martin (2006): "Employer Willingness to Permit Phased Retirement: Why Are Some More Willing than Others?", Industrial and Labor Relations Review, 59, 525-546.

Imbens, G. W. (2004): "Nonparametric Estimation of Average Treatment Effects under Exogeneity: A Review", Review of Economics and Statistics, 86, 4-29.

Imbens, G. W., and J. M. Wooldridge (2009): "Recent Developments in the Econometrics of Program Evaluation", Journal of Economic Literature, 47, 5-86.

Joffe, M. M., T. R. Have, H. I. Feldman, and S. Kimmel (2004): "Model Selection, Confounder Control, and Marginal Structural Models", The American Statistician, 58-4, 272-279.

Kim, H., and S. A. DeVaney (2005): "The Selection of Partial or Full Retirement by Older Workers", Journal of Family and Economic Issues, 26, 371-394.

Lechner, M., R. Miquel, and C. Wunsch (2011): "Long-Run Effects of Public Sector Sponsored Training in West Germany", Journal of the European Economic Association, 9, 742-784.

Lechner, M. and C. Wunsch (2013): "Sensitivity of Matching-Based Program Evaluations to the Availability of Control Variables", Labour Economics, 21, 111-121.

Machado, C. S., and M. Portela (2012): "Hours of Work and Retirement Behavior", IZA Discussion Paper 6270.

MacKinnon, J. G. (2006). "Bootstrap Methods in Econometrics", The Economic Record, 82, 2-18.

OECD (2009): Live Longer, Work Longer. 
Robinson, C., and R. Clark (2010): "Retiree Health Insurance and Disengagement from a Career Job", Journal of Labor Research, 31, 247-262.

Rosenbaum, P. R., and D. B.Rubin (1983): "The central role of the propensity score in observational studies for causal effects", Biometrika, 70, 41-50.

Rubin, D. B. (1979): "Using Multivariate Matched Sampling and Regression Adjustment to Control Bias in Observational Studies", Journal of the American Statistical Association, 74, 318-328.

Ruhm, C.J. (1990): "Bridge Jobs and Partial Retirement", Journal of Labor Economics, 8, 482-501.

Wunsch, C. (2013): “Optimal Use of Labor Market Policies: The Role of Job Search Assistance“, Review of Economics and Statistics, 95 (3), online early excess, doi: 10.1162/REST_a_00371.

Wunsch, C., and M. Lechner (2008): "What Did All the Money Do? On the General Ineffectiveness of Recent West German Labour Market Programmes", Kyklos, 61, 134-174. 


\section{Appendix A: Probit specifications for selection into PWE}

Table A1: Probit specifications for males in West Germany

\begin{tabular}{|c|c|c|c|c|c|c|}
\hline & \multicolumn{2}{|c|}{ Aged 31-40 } & \multicolumn{2}{|c|}{ Aged 41-50 } & \multicolumn{2}{|c|}{ Aged 51 plus } \\
\hline & $\begin{array}{c}\text { Coeffi- } \\
\text { cient }\end{array}$ & $\begin{array}{c}\text { P-value } \\
\text { in } \%\end{array}$ & $\begin{array}{c}\text { Coeffi- } \\
\text { cient }\end{array}$ & $\begin{array}{c}\text { P-value } \\
\text { in } \%\end{array}$ & $\begin{array}{c}\text { Coeffi- } \\
\text { cient }\end{array}$ & $\begin{array}{c}\text { P-value } \\
\text { in } \%\end{array}$ \\
\hline Constant & -6.984 & 0.0 & -7.211 & 0.0 & -5.948 & 0.0 \\
\hline \multicolumn{7}{|l|}{ Firm characteristics } \\
\hline Log number of employees & 0.792 & 0.0 & 0.966 & 0.0 & 0.902 & 0.0 \\
\hline 501-1000 employees & -0.503 & 0.0 & -0.818 & 0.0 & -0.697 & 0.0 \\
\hline Share of employees being 55 or older & 2.203 & 0.0 & 1.323 & 0.4 & 0.233 & 67.1 \\
\hline Share of employees leaving the firm & -1.480 & 0.0 & -1.403 & 0.0 & -0.311 & 8.1 \\
\hline Share of unskilled employees & -0.387 & 0.1 & -0.366 & 0.2 & 0.155 & 27.4 \\
\hline Single branch firm & 0.326 & 0.0 & 0.319 & 0.0 & 0.222 & 0.0 \\
\hline High number of absences is a problem & -0.426 & 0.0 & -0.522 & 0.0 & -0.705 & 0.0 \\
\hline Staff shortage is problem & -0.333 & 0.0 & -0.266 & 0.0 & -0.458 & 0.0 \\
\hline No working-time accounts & 0.000 & 99.3 & 0.192 & 0.0 & 0.310 & 0.0 \\
\hline Reorganization of corporate structure & 0.617 & 0.0 & 0.615 & 0.0 & 0.543 & 0.0 \\
\hline Pay tied to collective agreement & -0.751 & 0.0 & -0.656 & 0.0 & -0.739 & 0.0 \\
\hline Manufacturing industry & 0.439 & 0.0 & 0.508 & 0.0 & 0.564 & 0.0 \\
\hline \multicolumn{7}{|l|}{ Employee characteristics } \\
\hline Age & 0.006 & 49.0 & 0.001 & 85.0 & 0.001 & 89.1 \\
\hline No German citizen & 0.289 & 0.1 & -0.111 & 18.3 & -0.014 & 86.8 \\
\hline University entrance degree (Abitur) & -0.216 & 3.4 & -0.272 & 0.2 & -0.258 & 1.1 \\
\hline No vocational degree & 0.041 & 59.3 & 0.034 & 64.6 & -0.019 & 82.7 \\
\hline Manufacturing occupation & 0.226 & 0.0 & 0.231 & 0.0 & 0.407 & 0.0 \\
\hline Service occupation & 0.153 & 3.8 & 0.025 & 70.9 & 0.138 & 3.5 \\
\hline Unskilled worker & 0.249 & 0.1 & 0.383 & 0.0 & 0.291 & 0.1 \\
\hline Clerk & 0.104 & 20.1 & 0.196 & 0.8 & 0.188 & 1.3 \\
\hline Half-monthly earnings in EUR & 1.060 & 0.0 & 0.923 & 0.0 & 0.414 & 0.1 \\
\hline Half-monthly earnings $>1500$ EUR & -0.476 & 0.0 & -0.388 & 0.0 & -0.069 & 47.8 \\
\hline Tenure & 0.059 & 30.6 & 0.064 & 24.1 & -0.007 & 92.3 \\
\hline Tenure 7 years & -0.192 & 12.9 & -0.441 & 0.0 & -0.428 & 0.8 \\
\hline \multicolumn{7}{|l|}{ Regional characteristics } \\
\hline Big agglomeration & -0.653 & 0.0 & -0.629 & 0.0 & -0.650 & 0.0 \\
\hline Local unemployment rate & 0.131 & 0.0 & 0.097 & 0.0 & 0.080 & 0.0 \\
\hline Northern Germany & -0.459 & 0.0 & -0.345 & 0.2 & -0.577 & 0.0 \\
\hline Central Germany & -0.150 & 0.8 & -0.102 & 7.3 & -0.146 & 3.1 \\
\hline Number of individual observations & 4098 & & 4269 & & 3390 & \\
\hline Efron's $R^{2}$ & 0.26 & & 0.28 & & 0.28 & \\
\hline
\end{tabular}

Note: All variables are measured in 2000 or relative to June 30, 2000. 
Table A2: Probit specifications for females in West Germany

\begin{tabular}{|c|c|c|c|c|c|c|}
\hline & \multicolumn{2}{|c|}{ Aged 31-40 } & \multicolumn{2}{|c|}{ Aged 41-50 } & \multicolumn{2}{|c|}{ Aged 51 plus } \\
\hline & $\begin{array}{l}\text { Coeffi- } \\
\text { cient }\end{array}$ & $\begin{array}{l}\text { P-value } \\
\text { in } \%\end{array}$ & $\begin{array}{l}\text { Coeffi- } \\
\text { cient }\end{array}$ & $\begin{array}{l}\text { P-value } \\
\text { in } \%\end{array}$ & $\begin{array}{l}\text { Coeffi- } \\
\text { cient }\end{array}$ & $\begin{array}{l}\text { P-value } \\
\text { in } \%\end{array}$ \\
\hline Constant & -4.917 & 0.0 & -4.403 & 0.0 & -4.070 & 0.0 \\
\hline \multicolumn{7}{|l|}{ Firm characteristics } \\
\hline Log number of employees & 0.795 & 0.0 & 0.678 & 0.0 & 0.694 & 0.0 \\
\hline Share of employees being 55 or older & -0.529 & 37.4 & -0.165 & 75.5 & -1.113 & 6.8 \\
\hline Share of employees leaving the firm & -0.291 & 39.5 & -1.322 & 0.0 & -0.318 & 33.9 \\
\hline Share of unskilled employees & -1.154 & 0.0 & -0.711 & 0.0 & -0.624 & 0.0 \\
\hline Single branch firm & 0.058 & 31.9 & -0.058 & 30.8 & -0.013 & 85.6 \\
\hline High number of absences is a problem & -0.335 & 0.0 & -0.307 & 0.0 & -0.129 & 10.7 \\
\hline Staff shortage is problem & -0.645 & 0.0 & -0.684 & 0.0 & -0.668 & 0.0 \\
\hline No working-time accounts & 0.050 & 43.7 & -0.109 & 8.5 & -0.241 & 0.2 \\
\hline Reorganization of corporate structure & 0.709 & 0.0 & 0.572 & 0.0 & 0.298 & 0.0 \\
\hline Pay tied to collective agreement & -0.677 & 0.0 & -0.454 & 0.0 & -0.386 & 0.0 \\
\hline Trade sector & -0.281 & 1.0 & -0.015 & 88.3 & 0.211 & 11.0 \\
\hline Service sector & -0.544 & 0.0 & -0.177 & 4.4 & -0.427 & 0.0 \\
\hline \multicolumn{7}{|l|}{ Employee characteristics } \\
\hline Age & -0.003 & 73.1 & -0.017 & 4.5 & -0.022 & 5.4 \\
\hline No German citizen & 0.298 & 0.4 & 0.324 & 0.0 & 0.367 & 0.1 \\
\hline No vocational degree & -0.049 & 48.6 & 0.043 & 50.2 & 0.040 & 59.0 \\
\hline $\begin{array}{l}\text { Manufacturing, technical, construction } \\
\text { occupation }\end{array}$ & -0.399 & 0.0 & -0.205 & 2.7 & -0.068 & 55.6 \\
\hline Low-skilled service occupation & -0.516 & 0.0 & -0.370 & 0.0 & 0.002 & 98.2 \\
\hline Other occupation & -0.030 & 74.8 & 0.076 & 38.0 & 0.143 & 15.6 \\
\hline Part-time worker & 0.515 & 0.0 & 0.535 & 0.0 & 0.531 & 0.0 \\
\hline Half-monthly earnings in EUR & 0.400 & 0.0 & 0.811 & 0.0 & 0.751 & 0.0 \\
\hline Half-monthly earnings $>1500$ EUR & -0.330 & 0.2 & -0.369 & 0.1 & 0.043 & 78.7 \\
\hline Tenure & 0.203 & 0.1 & 0.305 & 0.0 & 0.251 & 0.1 \\
\hline Tenure 7 years & -0.122 & 24.1 & -0.248 & 2.5 & -0.370 & 1.7 \\
\hline Out of the labour force in last 4 years & -0.067 & 33.7 & 0.041 & 60.1 & 0.119 & 23.8 \\
\hline Out of the labour force in last 10 years & 0.107 & 9.9 & -0.020 & 75.3 & 0.001 & 98.6 \\
\hline \multicolumn{7}{|l|}{ Regional characteristics } \\
\hline Big agglomeration & -0.454 & 0.0 & -0.462 & 0.0 & -0.421 & 0.0 \\
\hline Local unemployment rate & 0.089 & 0.0 & 0.112 & 0.0 & 0.122 & 0.0 \\
\hline Northern Germany & & & -0.511 & 0.0 & -0.806 & 0.0 \\
\hline Central Germany & -0.235 & 0.0 & -0.400 & 0.0 & -0.286 & 0.0 \\
\hline Number of individual observations & 3323 & & 3412 & & 2227 & \\
\hline Efron's R ${ }^{2}$ & 0.32 & & 0.31 & & 0.30 & \\
\hline
\end{tabular}

Note: $\quad$ All variables are measured in 2000 or relative to June 30, 2000. 
Table A3: Probit specifications for males in East Germany

\begin{tabular}{|c|c|c|c|c|c|c|}
\hline & \multicolumn{2}{|c|}{ Aged 31-40 } & \multicolumn{2}{|c|}{ Aged 41-50 } & \multicolumn{2}{|c|}{ Aged 51 plus } \\
\hline & $\begin{array}{l}\text { Coeffi- } \\
\text { cient }\end{array}$ & $\begin{array}{l}\text { P-value } \\
\text { in } \%\end{array}$ & $\begin{array}{l}\text { Coeffi- } \\
\text { cient }\end{array}$ & $\begin{array}{l}\text { P-value } \\
\text { in } \%\end{array}$ & $\begin{array}{c}\text { Coeffi- } \\
\text { cient }\end{array}$ & $\begin{array}{l}\text { P-value } \\
\text { in } \%\end{array}$ \\
\hline Constant & -3.275 & 0.0 & -1.277 & 0.7 & -2.279 & 0.1 \\
\hline \multicolumn{7}{|l|}{ Firm characteristics } \\
\hline Log number of employees & 0.155 & 0.1 & 0.029 & 51.9 & 0.138 & 1.1 \\
\hline $\begin{array}{l}\text { Share of employees with university or } \\
\text { college degree }\end{array}$ & 4.167 & 0.0 & 4.554 & 0.0 & 3019 & 00 \\
\hline Share of employees being 55 or older & -0.670 & 13.0 & 0.033 & 93.7 & 1.946 & 0.0 \\
\hline No working-time accounts & 0.178 & 0.4 & 0.280 & 0.0 & 0.065 & 45.5 \\
\hline $\begin{array}{l}\text { Share of employees leaving the firm } \\
\text { (survey) }\end{array}$ & -7.419 & 0.0 & -9.973 & 0.0 & -10950 & Oم \\
\hline No reorganization & 0.002 & 97.7 & -0.035 & 59.8 & -0.307 & 0.0 \\
\hline Looking for staff in future & 0.833 & 0.0 & 1.071 & 0.0 & 1.047 & 0.0 \\
\hline Hiring skilled workers is problem & 0.365 & 0.0 & 0.157 & 0.9 & 0.164 & 3.6 \\
\hline Hiring young workers is problem & -0.525 & 0.0 & -0.472 & 0.0 & -0.863 & 0.0 \\
\hline High number of absences is a problem & 0.671 & 0.0 & 0.681 & 0.0 & 0.560 & 0.0 \\
\hline Foreign-owned to more than $50 \%$ & -0.491 & 0.0 & -0.551 & 0.0 & -0.930 & 0.0 \\
\hline Trade sector & 0.964 & 0.0 & 1.097 & 0.0 & 0.767 & 0.0 \\
\hline Service sector & -0.531 & 0.0 & -0.518 & 0.0 & -0.633 & 0.0 \\
\hline \multicolumn{7}{|l|}{ Employee characteristics } \\
\hline Age & -0.003 & 71.0 & -0.027 & 0.1 & -0.009 & 37.7 \\
\hline University entrance degree (Abitur) & -0.121 & 48.1 & -0.169 & 21.1 & 0.232 & 22.1 \\
\hline Vocational degree & 0.392 & 0.0 & 0.139 & 14.5 & 0.136 & 25.3 \\
\hline University or college degree & 0.427 & 4.8 & 0.312 & 6.3 & -0.099 & 68.1 \\
\hline Technical occupation & -0.453 & 0.0 & -0.382 & 0.0 & -0.142 & 8.8 \\
\hline Higher-skilled service occupation & -0.602 & 0.0 & -0.578 & 0.0 & -0.343 & 0.1 \\
\hline Low-skilled service occupation & 0.075 & 44.7 & -0.135 & 13.6 & -0.084 & 45.0 \\
\hline Other occupation & -0.403 & 0.0 & -0.451 & 0.0 & -0.361 & 0.3 \\
\hline Skilled worker & -0.378 & 0.0 & -0.301 & 0.0 & -0.116 & 22.3 \\
\hline Clerk & -0.284 & 0.8 & -0.360 & 0.1 & -0.261 & 4.9 \\
\hline Half-monthly earnings in EUR & 1.118 & 0.0 & 1.562 & 0.0 & 0.265 & 20.6 \\
\hline Half-monthly earnings $>1500$ EUR & -0.209 & 8.8 & -0.415 & 0.0 & -0.037 & 76.1 \\
\hline $\begin{array}{l}\text { Cumulated earnings from employment in } \\
\text { last } 10 \text { years }\end{array}$ & -0.131 & 25.4 & -0.298 & 2.3 & 0.105 & 40.7 \\
\hline Tenure & 0.517 & 0.0 & 0.523 & 0.0 & 0.530 & 0.0 \\
\hline Tenure 7 years & -0.713 & 0.0 & -0.854 & 0.0 & -0.766 & 0.0 \\
\hline Unemployed in last 4 years & -0.344 & 1.0 & -0.645 & 0.0 & -0.583 & 2.6 \\
\hline Unemployed in last 10 years & -0.085 & 19.5 & -0.203 & 0.2 & -0.004 & 96.8 \\
\hline Out of the labour force in last 4 years & -0.021 & 82.4 & -0.026 & 77.4 & -0.002 & 98.8 \\
\hline Out of the labour force in last 10 years & 0.320 & 0.0 & 0.177 & 0.1 & 0.113 & 10.9 \\
\hline Fraction employed 9-10 years before & 1.015 & 0.0 & 1.014 & 0.0 & 1.257 & 0.0 \\
\hline \multicolumn{7}{|l|}{ Regional characteristics } \\
\hline Rural area & 0.271 & 0.0 & 0.395 & 0.0 & 0.390 & 0.0 \\
\hline Number of individual observations & 4145 & & 4894 & & 2902 & \\
\hline Efron's $R^{2}$ & 0.33 & & 0.36 & & 0.36 & \\
\hline
\end{tabular}

Note: $\quad$ All variables are measured in 2000 or relative to June 30, 2000. 
Table A4: Probit specifications for females in East Germany

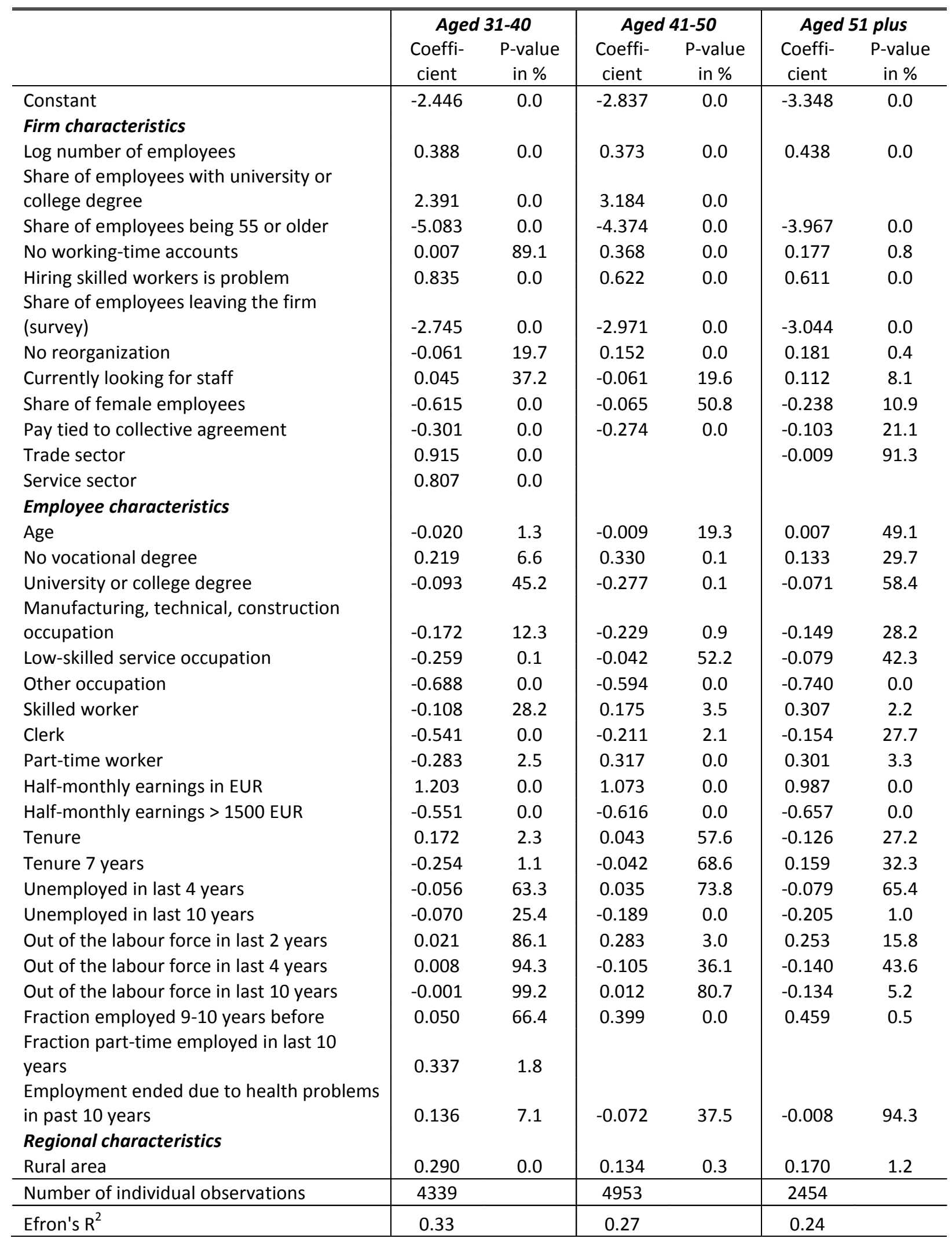

Note: $\quad$ All variables are measured in 2000 or relative to June 30, 2000. 